\title{
Socioeconomic inequalities in tobacco, alcohol and illicit drug use: evidence from Iranian Kurds
}

Farid Najafi, ${ }^{1}$ Mohammad Hajizadeh, ${ }^{2}$ Yahya Pasdar, ${ }^{3}$ Yahya Salimi, ${ }^{4}$ Behrooz Hamzeh, ${ }^{5}$ Behzad Karami Matin, ${ }^{6}$ Bakhtiar Piroozi ${ }^{7}$ and Satar Rezaei ${ }^{1}$

${ }^{1}$ Research Center for Environmental Determinants of Health, Health Institute, Kermanshah University of Medical Sciences Kermanshah, Islamic Republic of Iran. (Correspondence to: S. Rezaei: satarrezaei@gmail.com). ${ }^{2}$ School of Health Administration, Faculty of Health, Dalhousie University, Halifax, Canada. ${ }^{3}$ Research Center for Environmental Determinants of Health, Health Institute, Kermanshah University of Medical Sciences Kermanshah, Islamic Republic of Iran. ${ }^{4}$ Social Development and Health Promotion Research Center, Health Institute, Kermanshah University of Medical Sciences, Kermanshah, Islamic Republic of Iran. ${ }^{5}$ Research Center for Environmental Determinants of Health, Health Institute, Kermanshah University of Medical Sciences Kermanshah, Islamic Republic of Iran. ${ }^{6}$ Research Center for Environmental Determinants of Health, Health Institute, Kermanshah University of Medical Sciences Kermanshah, Islamic Republic of Iran. ${ }^{7}$ Social Determinants of Health Research Center, Research Institute for Health Development, Kurdistan University of Medical Sciences, Sanandaj, Islamic Republic of Iran.

\begin{abstract}
Background: The associations between socioeconomic status (SES) and tobacco use, alcohol consumption and drug use are poorly understood in the Islamic Republic of Iran.

Aims: To measure education- and wealth-related inequalities in cigarette smoking, hookah smoking, illicit drug use and alcohol consumption in Kermanshah Province, Islamic Republic of Iran.

Methods: We used baseline data from the Ravansar Noncommunicable Disease (RaNCD) study. The study collected information on socioeconomic and demographic characteristics, cigarette and hookah smoking, alcohol consumption and illicit drug use of 10015 adults aged $\geq 35$ years between 2014 and 2016. The relative concentration index and absolute concentration index were used to measure education- and wealth-related inequalities in cigarette smoking, hookah smoking, illicit drug use and alcohol consumption.

Results: Cigarette smoking was concentrated among less-educated and less-wealthy men and women. Similarly, illicit drug use was concentrated among lower-SES men. In contrast, hookah smoking and alcohol consumption were more prevalent among higher-SES men.

Conclusions: There were education- and wealth-related inequalities in tobacco, alcohol and illicit drug use in the west of the Republic of Iran. Future studies should aim to identify the main socioeconomic determinants of these inequalities in Kermanshah Province and generally in the Islamic Republic of Iran.

Keywords: socioeconomic inequalities, cigarette and hookah smoking, alcohol consumption, illicit drug use, Islamic Republic of Iran

Citation: Najafi F; Hajizadeh M; Pasdar Y; Salimi Y; Hamzeh B; Karami Matin B et al. Socioeconomic inequalities in tobacco, alcohol and illicit drug use: evidence from Iranian Kurds. East Mediterr Health J. 2020;26(10):1294-1302. https://doi.org/10.26719/emhj.20.007

Received: 10/09/18; accepted: 25/03/19

Copyright (C) World Health Organization (WHO) 2020. Open Access. Some rights reserved. This work is available under the CC BY-NC-SA 3.0 IGO license (https://creativecommons.org/licenses/by-nc-sa/3.0/igo)
\end{abstract}

\section{Introduction}

Tobacco use, excessive alcohol consumption and illicit drug use have a negative impact on society, health systems and human development $(1,2)$. There are substantial social and economic costs associated with the use of these substances globally. For example, the annual cost of alcohol use in the United States of America (USA) is estimated to be US\$ 185 billion and US\$ 181 billion for illicit drugs and substance abuse, respectively $(1,3)$. Drug and alcohol use in the Islamic Republic of Iran is responsible for 7.7 and 0.16 deaths per 100000 population in men and 0.62 and 0.02 in women, respectively (4). Smoking also imposes a considerable burden on health systems and societies (5-6), and is well documented in the Islamic Republic of Iran (7-9). For example, a study by Rezaei and colleagues (9) demonstrated that the total economic cost of the 3 most common smoking-attributable diseases, namely lung cancer, chronic obstructive pulmonary disease and ischaemic heart disease, in the Islamic Republic of Iran was US\$ 1.46 billion in 2014, including US\$ 1.05 billion (71.7\%) indirect and US\$ 0.41 billion (28.3\%) direct costs.

The relationships between socioeconomic status (SES) of individuals (e.g., income, wealth, educational attainment and occupational status) and health status and risky health behaviour are well documented. Socioeconomic-related inequalities in health and risky health behaviour are considered serious and persistent health policy concerns in all countries, regardless of their development status $(10-11)$. Socioeconomic-related inequalities in risky health behaviour such as smoking and alcohol consumption have been investigated in some countries (12-13). However, the association between substance use and SES is poorly understood in the Islamic Republic of Iran. Measuring inequalities in risky health behaviour such as smoking, illicit drug use and alcohol consumption can provide useful information for health policy-makers to identify populations at risk of higher substance use and suggest interventions that will lead to healthier lifestyles. 
In this study, we aimed to quantify education- and wealth-related inequalities in cigarette smoking, alcohol consumption, illicit drug use and hookah smoking using relative concentration index $(R C)$ and absolute concentration index $(A C)$ in Kermanshah Province in West Islamic Republic of Iran. The results of this study will help to identify the most appropriate socioeconomic groups for possible interventions to reduce the prevalence of substance use in the Islamic Republic of Iran.

\section{Methods}

\section{Study setting and sample}

This study focused on Ravansar County in Kermanshah Province, located in the western region of the Islamic Republic of Iran, close to the Iraqi border. The population consisted mainly of Iranian Kurds. The County had 3 urban healthcare centres, 2 rural healthcare centres and 32 active local health houses in rural areas. In this cross-sectional study, we used data from the Ravansar Noncommunicable Disease (RaNCD) cohort study. That study was 1 of 17 Prospective Epidemiological Research Studies in Iran (PERSIAN) cohort studies of Iranian adults. All PERSIAN cohort studies were established and conducted with the support and coordination of the Digestive Disease Research Institute and Ministry of Health and Medical Education to collect valuable information about NCDs from Iranian adults aged $\geq 35$ years. More information about PERSIAN cohort studies is available at http://persiancohort.com/. A total of 10015 adults (aged 35-65 years) were surveyed between 2014 and 2016 in the RaNCD cohort study. The survey collected information on the socioeconomic and demographic characteristics, smoking status, hookah smoking, alcohol consumption and illicit drug use of the participants in the study.

\section{Study variables}

The variables of interest were binary variables for cigarette smoking, hookah smoking, illicit drug use and alcohol consumption. The cigarette smoking variable was identified using the question "Do you currently smoke at least 1 cigarette per day and have smoked 100 and more cigarettes in your lifetime?". The illicit drug use variable was derived from the question "Have you used any illicit drug (cannabis, opium, morphine or heroin) in your lifetime?". The alcohol consumption variable was based on the question "Have you consumed alcohol in your lifetime?". The hookah smoking variable was constructed using the question "Have you smoked hookah in your lifetime?". We created a binary variable for each of the outcome variables if the participant answered "yes" to the relevant questions, and o otherwise. We analysed socioeconomic inequalities in 4 variables of interest based on years of education and a wealth index (WI) as the two indicators of SES. WI was constructed using principal component analysis, based on information collected in the RaNCD study on household goods.

\section{Statistical analysis}

We used the concentration index approach to measure education- and wealth-related inequalities for cigarette smoking, hookah smoking, illicit drug use and alcohol consumption among adults in Ravansar County. We measured both relative and absolute measures of concentration index to quantify education- and wealth-related inequalities in cigarette smoking, hookah smoking, illicit drug use and alcohol consumption.

$R C$ was calculated based on the concentration curve. The y axis showed the cumulative percentage of health variables (cigarette smoking, hookah smoking, illicit drug use and alcohol consumption) and the $\mathrm{x}$ axis presented the cumulative percentage of population ordered based on SES (e.g., years of education or wealth index). RC was defined as twice the area between the concentration curve and the line of perfect equality, and the value ranged between -1 and +1 . If $R C$ was negative (positive), it indicated that the health variable was concentrated among socioeconomically disadvantaged (advantaged) people, and the curve lay above (under) the line of perfect equality (14). The o value of the index suggested perfect equality. We used the convenient regression method to calculate $R C$ as follows:

$$
2 \sigma_{r}^{2}\left(\frac{y_{i}}{\mu}\right)=\alpha+\varphi r_{i}+\varepsilon_{i}
$$

Where $y_{i}$ denotes the outcome variable (e.g., cigarette smoking, hookah smoking, illicit drug use or alcohol consumption) for individual $i$; $\mu$ shows the mean of the health variable for the sample; $r_{i}$ is the fractional rank of individual $i ; \sigma^{2}$ represents the variance of fractional rank; and $\varphi$ represents $R C$ (15).

Since the outcome variables in the study were binary, as per Wagstaff's suggestion (16), we normalized RC and reported normalized relative concentration index, $R C_{n}=R C / 1-\mu$, where $\mu$ represents the proportion of health variable in the sample. We also used the modified absolute concentration index $\left(A C_{m}=4 \mu * R C\right)$ suggested by Erreygers (17), to report absolute education- and wealthrelated inequalities. Similar to $R C_{n}, A C_{m}$ ranged between -1 and +1 , with the value of $o$ indicating perfect equality. If the sign of this index was positive (negative), the outcome variable was concentrated among higher (lower) SES people. The data analysis was performed using Stata version 12 statistical software (Stata Corporation, College Station, TX, USA). $P<0.05$ was considered statistically significant.

\section{Ethical statement}

Written informed consent was obtained from each participant after explaining the purpose of the study. The study was approved by the Ethics Committee of the Deputy of Research at Kermanshah University of Medical Sciences (KUMS.REC.1394.315). Each participant was given the right to terminate the data collection process 
at any point. Those who did not provide consent to participate in the study were excluded from data collection.

\section{Results}

\section{Descriptive results}

A total of 10015 adults aged 35-65 years participated in the study, of whom 5271 (52.6\%) were women and 4744 (47.4\%) were men. The mean age of all respondents was 47.3 (standard deviation; 8.3) years: 47 (8.1) years for men and 47.5 (8.4) years for women. Most the study population was married (90.2\%). The descriptive characteristics of the participants included in the study according to sex are presented in Table 1. The overall cigarette smoking prevalence was $11.9 \%$ [95\% confidence interval (CI): $11.3^{-}$ $12.6 \%$. The prevalence of cigarette smoking was higher among men than women. The overall prevalence of hookah smoking, illicit drug use and alcohol consumption was $3.7 \%(3.3-4 \%), 3.0 \%(2.7-3.3 \%)$, and $6.3 \%(5.8-6.8 \%)$, respectively. The prevalence of cigarette smoking, hookah smoking, illicit drug use and alcohol consumption were significantly higher among male than female participants $(P<0.001)$. There were $1082(22.8 ; 21.6-24 \%)$ men who were current smokers, compared with 115 (2.2\%; $1.8-$ $2.6 \%)$ women. The prevalence of hookah smoking, illicit drug use and alcohol consumption among men was $7.1 \%$ (6.3-7.8\%), 6.1\% (5.5-6.8\%), and $13.2 \%(12.3-14.2 \%)$, respectively. The corresponding figures among women were $0.6 \%(0.4-0.8 \%), 0.2 \%(0.08-0.3 \%)$, and $0.1 \%$ (0.02-0.2\%).

\section{Socioeconomic-related inequalities}

Table 2 reports education- and wealth-related inequalities in cigarette smoking, hookah smoking, illicit drug

\begin{tabular}{|c|c|c|c|}
\hline \multirow[t]{2}{*}{ Sociodemographic characteristics } & \multirow[t]{2}{*}{ Total sample (\%) } & \multicolumn{2}{|c|}{ Sex } \\
\hline & & Male (\%) & Female (\%) \\
\hline \multicolumn{4}{|l|}{ Age (yr) } \\
\hline $35-44$ & $4343(43.1)$ & $2073(43.7)$ & $2270(43.1)$ \\
\hline $45-54$ & $3337(32.1)$ & $1645(34.7)$ & $1692(32.1)$ \\
\hline $55-65$ & $2335(24.8)$ & $1026(21.6)$ & $1309(24.8)$ \\
\hline \multicolumn{4}{|l|}{ Marital status } \\
\hline Never married & $422(4.2)$ & $97(2.0)$ & $325(6.2)$ \\
\hline Married & $9028(90.2)$ & $4607(97.1)$ & $4421(83.9)$ \\
\hline Divorced and widowed & $565(5.6)$ & $40(0.9)$ & $525(9.9)$ \\
\hline \multicolumn{4}{|l|}{ Educational attainment (yr) } \\
\hline$<4$ & $3818(38.1)$ & $1026(21.6)$ & $2792(53)$ \\
\hline $4-7$ & $3225(32.2)$ & $1468(30.9)$ & $1757(33.3)$ \\
\hline $8-11$ & $1277(12.8)$ & $903(19.0)$ & 374.1) \\
\hline$>12$ & $1694(16.9)$ & $1347(28.4)$ & $347(6.6)$ \\
\hline \multicolumn{4}{|c|}{ Household living standard (household wealth) } \\
\hline 1st quintile (lowest) & $2033(20.3)$ & $587(12.4)$ & $1446(27.4)$ \\
\hline 2nd quintile & 2119 (21.7) & $926(19.5)$ & $1193(22.6)$ \\
\hline 3rd quintile & $1984(19.8)$ & $1010(21.3)$ & $974(18.5)$ \\
\hline 4th quintile & $2083(20.8)$ & $833(17.6)$ & $1250(23.7)$ \\
\hline 5th quintile (highest) & $1796(17.9)$ & $1388(29.3)$ & $408(7.7)$ \\
\hline \multicolumn{4}{|l|}{ Cigarette smoking } \\
\hline Yes & 1197 (11.9) & $1082(22.8)$ & $115(2.2)$ \\
\hline No & $8818(88.1)$ & $3662(77.2)$ & $5156(97.8)$ \\
\hline \multicolumn{4}{|l|}{ Illicit drug use } \\
\hline Yes & $300(3.0)$ & $291(6.1)$ & $9(0.2)$ \\
\hline No & 9715 (97) & $4453(93.9)$ & $5262(99.8)$ \\
\hline \multicolumn{4}{|l|}{ Alcohol consumption } \\
\hline Yes & $632(6.3)$ & $628(13.2)$ & $4(0.1)$ \\
\hline No & $9383(93.7)$ & $4116(86.8)$ & 5267 (99.9) \\
\hline \multicolumn{4}{|l|}{ Hookah smoking } \\
\hline Yes & $366(3.7)$ & $335(7.1)$ & $31(0.6)$ \\
\hline No & $9649(96.3)$ & 4409 (92.9) & (99.4) \\
\hline
\end{tabular}


Table $2 \mathrm{RC}_{\mathrm{n}}$ and $\mathrm{AC}_{\mathrm{m}}$ for cigarette smoking, hookah smoking, drug use and alcohol consumption according to wealth and years of education

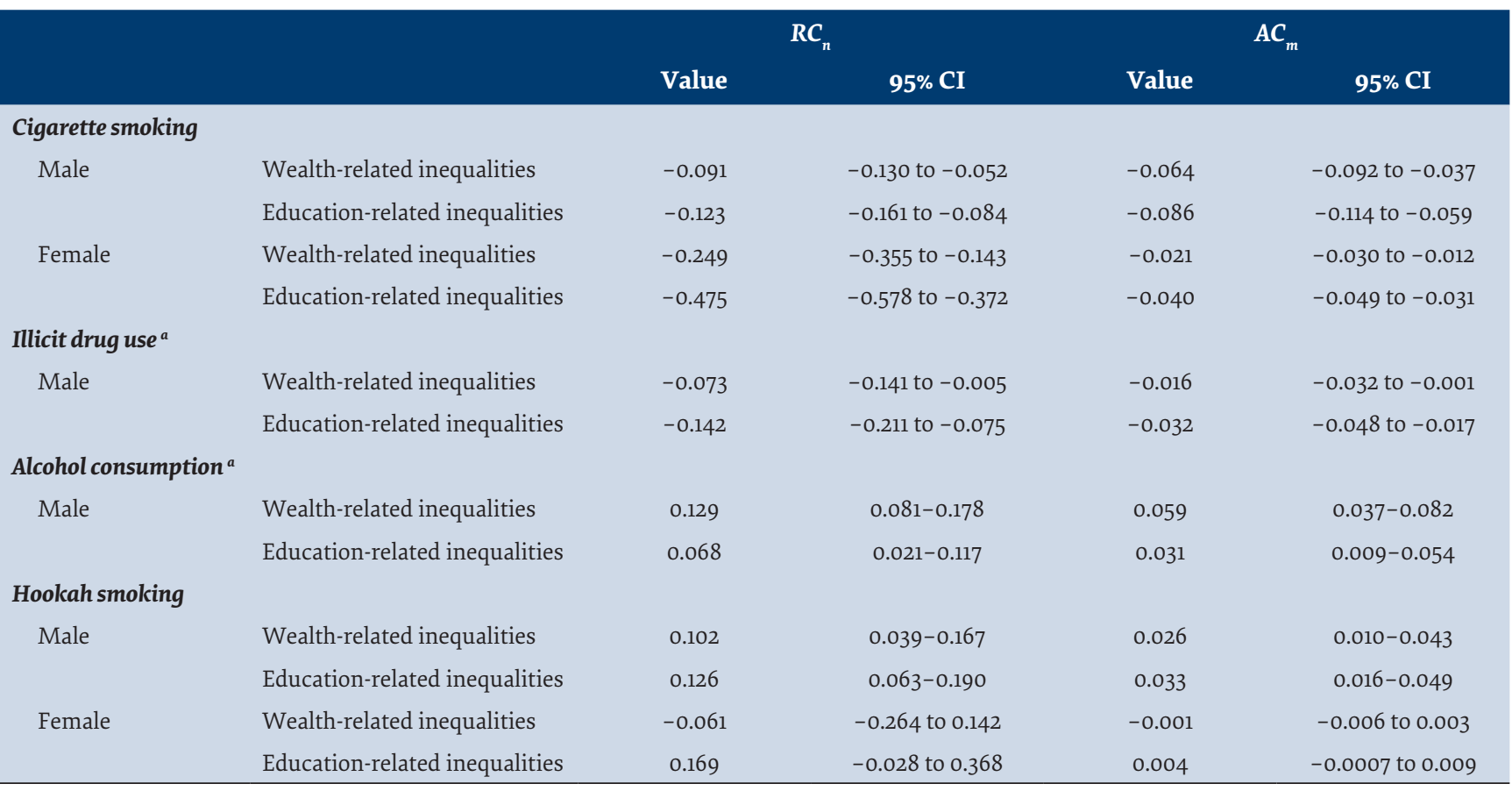

use and alcohol consumption for men and women. Based on the $R C_{n}$ and $A C_{m}$, cigarette smoking was concentrated among less-educated and less-wealthy men [education-related inequalities: $R C_{n}-0.123$ (95\% CI: -0.161 to $-0.084)$ and $A C_{m}-0.086(-0.114$ to -0.059$)$ and wealth-related inequalities: $R C_{\mathrm{n}}-0.091(-0.130$ to -0.052$)$ and $A C_{m}$ ?0.064 (-0.092 to -0.037$)$ ] and women [education-related inequalities: $R C_{n}-0.475(-0.578$ to -0.372$)$ and $A C_{m}$ $-0.040(-0.049$ to -0.031$)$ and wealth-related inequalities: $R C_{\mathrm{n}}-0.249(-0.355$ to -0.143$)$ and $A C_{m}-0.021$ ( -0.030 to $-0.012)]$. Similarly, illicit drug use was more concentrated among less-educated and poor men.

In contrast, the estimated the $R C_{n}$ and $A C_{m}$ suggested that alcohol consumption and hookah smoking were more prevalent among highly-educated and wealthier men, as illustrated by the positive values of $R C_{n}$ and $A C_{m}$ for alcohol consumption [education-related inequalities: $R C_{n} 0.068$ (0.021-0.117) and wealth-related inequalities: $A C_{m} 0.059$ (0.037-0.082) and hookah smoking ( $R C_{n} 0.126$ (0.063-0.190) and $\left.A C_{m} 0.026(0.010-0.043)\right]$. The $R C_{n}$ and $A C_{\mathrm{m}}$ suggested that hookah smoking was more prevalent among highly-educated and less-wealthy women, albeit the observed socioeconomic-related inequalities were not found to be significant.

Figure 1 shows the concentration curves for cigarette smoking, hookah smoking, illicit drug use and alcohol consumption for men. The curves for alcohol consumption and hookah smoking lie below the line of perfect equality; indicating that alcohol consumption and hookah smoking were concentrated mainly among socioeconomically advantaged (higher WI and moreeducated) men. The concentration curves for cigarette smoking and illicit drug use lie below the equality line, indicating the concentration of these variables among higher-SES men.

Figure 2 illustrates the concentration curves for cigarette smoking and hookah smoking among women. The curves for cigarette smoking lies above the line of perfect equality. This implies that cigarette smoking is more concentrated among poor SES women. On the contrary, the concentration curve for hookah smoking lies below the equality line when it was generated based on the education level of women, which shows that hookah smoking was concentrated among highereducated women.

\section{Discussion}

The financial and nonfinancial burdens of substance use such as tobacco use, illicit drug use and alcohol consumption are significant on health systems and societies as a whole. Although some studies have examined socioeconomic-related inequalities in risky health behaviour such as smoking and alcohol consumption in some countries, the association between SES and substance use in the Islamic Republic of Iran is poorly documented. In this study, for the first time, we examined education- and wealth-related inequalities in cigarette smoking, hookah smoking, illicit drug use and alcohol consumption among adults aged 35-65 years old in Kermanshah Province in the west of the Islamic Republic of Iran.

Our results revealed that cigarette smoking was concentrated among poor and less-educated men and women. These findings are consistent with studies conducted in other countries (18-20). For example, studies in Belgium in 2004 and 2008 suggested that the prevalence of smoking was 4.6 times higher among 
Figure 1 Concentration curve for cigarette smoking, hookah smoking, alcohol consumption and illicit drug use among men based on wealth index (A) and educational attainment (years) (B).

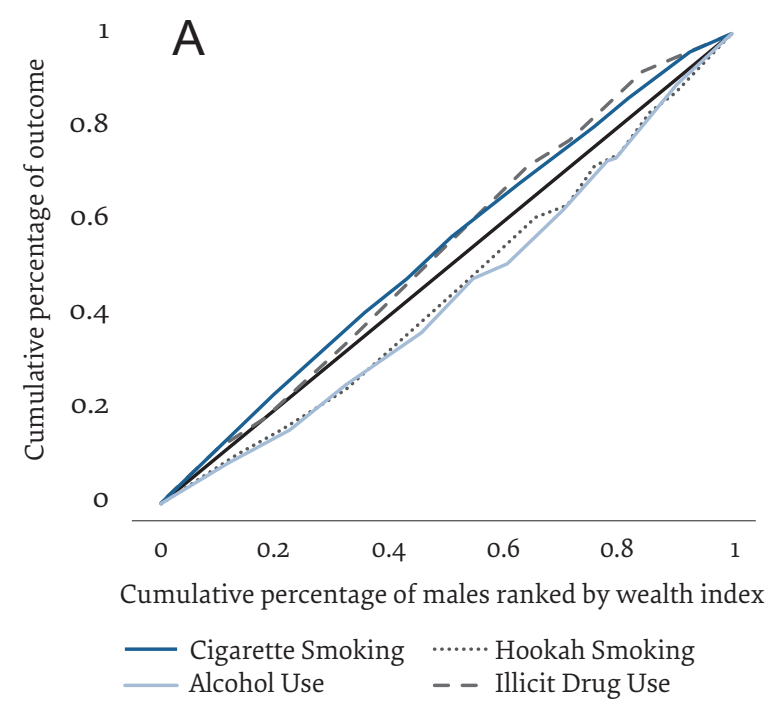

less-educated men compared to their more-educated counterparts (21). Corsi and colleagues (22) have investigated the socioeconomic pattern of smoking behaviour in Canada, which indicated a higher smoking rate among poor people. Barreto and colleagues (23) found that the probability of smoking was higher among low-income and less-educated individuals in Brazil. Moreover, Nagelhout and colleagues (20) showed that socioeconomically disadvantaged individuals were more likely to be smokers in the Netherlands. The negative association between smoking and education level may be explained by the fact that less-educated people have less information about the adverse effects of cigarette smoking and have less access to effective tobacco control programmes. Since cigarette smoking is mainly concentrated among less-educated and poor men and

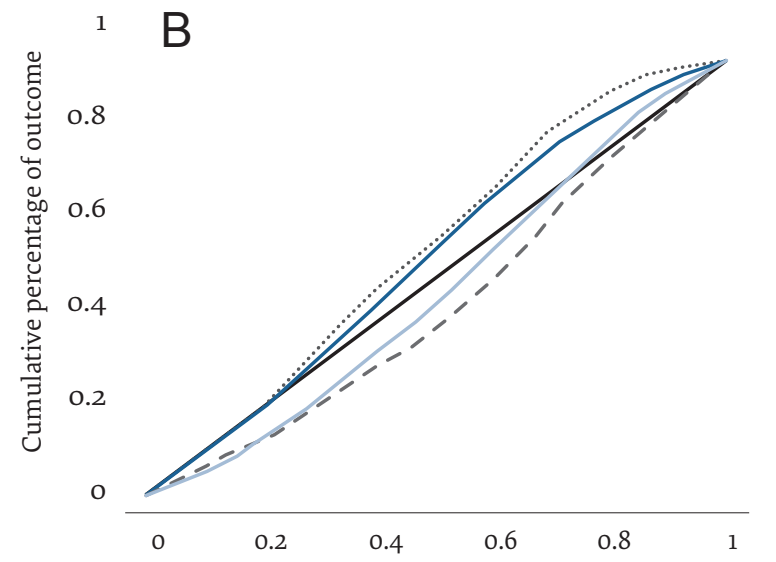

Cumulative percentage of males ranked by years of education

$$
\begin{array}{cc}
\text { C Cigarette Smoking } & \text {........ Hookah Smoking } \\
\text { Alcohol Use } & \text { - - Illicit Drug Use }
\end{array}
$$

women, smoking prevention and cessation interventions should focus on these groups in the Islamic Republic of Iran.

Our results showed that alcohol consumption and hookah smoking were more prevalent among higherSES men. We did not estimate socioeconomic-related inequalities for alcohol consumption for women because of the low number of alcohol users in the sample (4; $0.1 \%$ of women). This finding is consistent with studies conducted in other countries. For example, Patrick and colleagues (24) suggested that there was a significant positive association between higher SES and alcohol consumption among young American adults after controlling for covariates. Another study by Charitonidi and colleagues (25) showed a positive association between SES and alcohol consumption in Switzerland.

Figure 2 Concentration curve for cigarette smoking and hookah smoking among women based on wealth index (A) and educational attainment (years) (B).
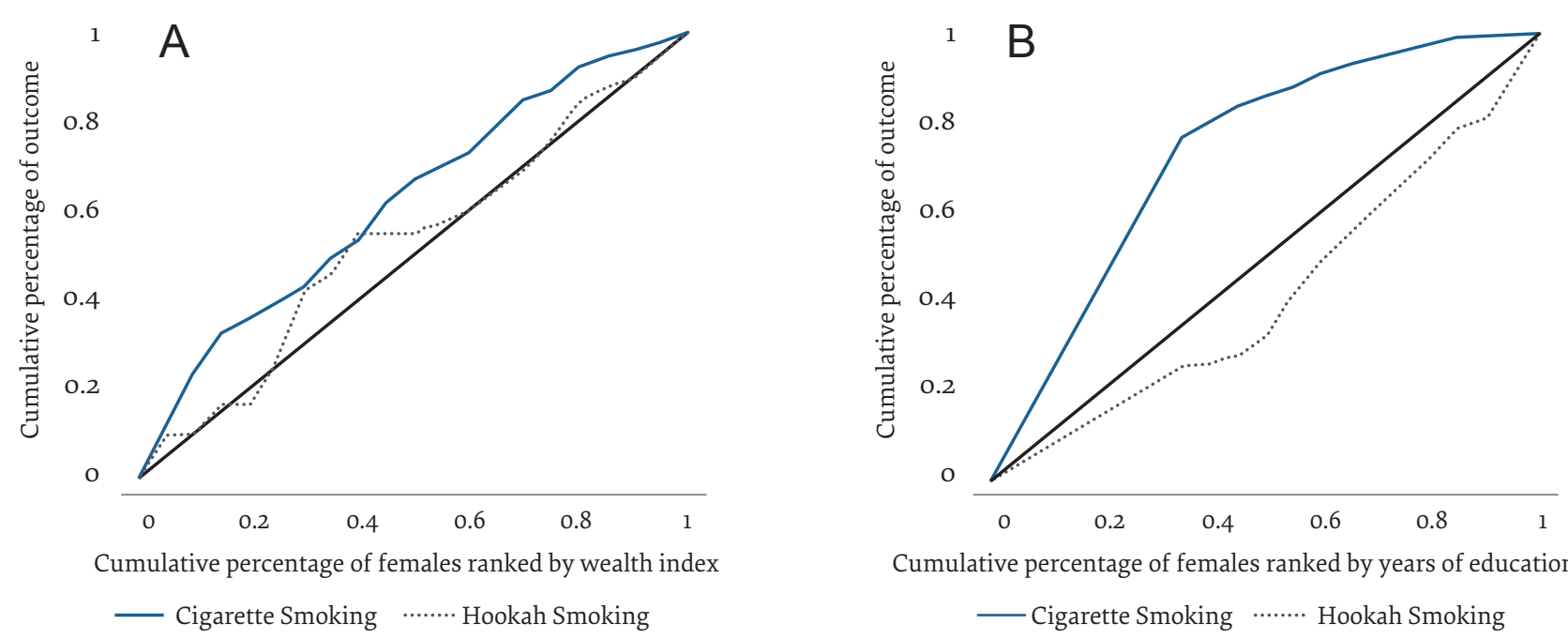

Cumulative percentage of females ranked by years of education

$$
\text { — Cigarette Smoking …… Hookah Smoking }
$$


Combes and colleagues (26) investigated the pattern of alcohol consumption among different SES groups in Sweden and found that alcohol consumption was more concentrated among individuals with higher SES. Higher rates of alcohol consumption were also observed among higher-SES individuals in Mexico (27) and Brazil (28). The main factors accounting for alcohol consumption vary from one region to another. The consumption of alcohol is considered to be against the religious norm in Islamic countries such as the Islamic Republic of Iran. Although sale and consumption of alcohol have been illegal in the Islamic Republic of Iran since the 1979 revolution, it is common to drink alcohol at some ceremonies and parties. Because of the illegality of alcohol consumption, alcoholic beverages are expensive in the Islamic Republic of Iran. Thus, one of the factors that explains the positive association between SES and alcohol consumption in the Islamic Republic of Iran is the affordability of alcohol by higher-SES individuals. The positive association between the ability to pay of individuals and drunkenness has been observed in previous studies $(29,30)$. For example, a study by Mohammad Poorasl et al. (31) found that higher SES was associated with higher alcohol consumption in the Islamic Republic of Iran.

Our results indicated a higher prevalence of illicit drug use among lower-SES men compared with women. We did not estimate socioeconomic-related inequalities for illicit drug use for women because of the low number of female illicit drug users in the sample ( $9 ; 0.4 \%$ of women). A study conducted by Redonnet et al. (32) indicated that the prevalence of substance use was higher among individuals with low SES in France. A study conducted by Amin $\square$ Esmaeili et al. (33) in the Islamic Republic of Iran also indicated an inverse association between SES and drug use disorders among individuals aged 15-65 years. Another study in the Islamic Republic of Iran also found that the probability of drug use is greater in individuals with low compared with high SES (34).

Our results also showed that hookah smoking was more concentrated among highly educated and wealthy men in the Islamic Republic of Iran. Although we observed that hookah smoking was more prevalent among highly educated and less-wealthy women, these socioeconomic inequalities were not found to be statistically significant. Several factors may explain the positive SES gradient of hookah smoking among Iranian men. The most common reasons could be erroneous beliefs about its low risks among the high-SES population. There is a common belief among the general population that hookah smoking is less addictive. This erroneous belief and high social acceptability (35) may have led to higher hookah smoking among more-affluent men because of their higher ability to pay. In a population-based study in Shiraz, Islamic Republic of Iran, Abdollahifard et al. (36) demonstrated a higher prevalence of hookah smoking among individuals with more years of education compared with those with fewer years of education (13.2\% vs $11.9 \%)$. Hessami et al. (37) also indicated that a higher prevalence of hookah smoking among well-educated young adults in the Islamic Republic of Iran.

Our study investigated education- and wealth-related inequalities in tobacco use, alcohol consumption and drug use among Iranians Kurds. The results suggested a higher level of cigarette smoking and illicit drug use among less-educated and less-wealthy individuals, whereas hookah smoking and alcohol consumption were more prevalent among higher-SES individuals. These results suggest that health policies and interventions to reduce the prevalence of substance use in the west of the Islamic Republic of Iran should focus on low-SES groups. In contrast, high-SES adults should be the target for reducing the prevalence of hookah smoking and alcohol consumption. Increasing awareness about adverse health effects of hookah smoking is recommended.

Our study had some limitations that should be considered in the interpretation of the results. First, information about substance use was self-reported, which could have caused recall bias and under-reporting of cigarette smoking, hookah smoking, illicit drug use and alcohol consumption. Under-reporting of substance use can be due to stigma and concerns about privacy. Second, this study was conducted in Ravansar County, in the west of the Islamic Republic of Iran; therefore, findings from this study may not be generalizable to other parts of the country.

\section{Conclusion}

This study demonstrated that there are education- and wealth-related inequalities in tobacco, alcohol and illicit drug use among adults in the west of the Islamic Republic of Iran. Thus, it is recommended that future studies should aim to identify the determinants of these inequalities to design interventions to reduce prevalence of substance use in Kermanshah Province and in the Islamic Republic of Iran as a whole.

\section{Acknowledgement}

The authors express their gratitude to Professor Reza Malekzadeh, Director of the PERSIAN cohort, and Dr. Hossein Poustchi, Executive Director of the PERSIAN cohort, for helping us to conduct this study in Ravansar.

Funding: This work was funded by the Iranian Ministry of Health and Medical Education and Kermanshah University of Medical Sciences.

Competing interests: None declared. 


\section{Inégalités socio-économiques en matière de tabagisme, de consommation d'alcool et de drogues illicites : témoignages des Kurdes iraniens}

\section{Résumé}

Contexte : Les associations entre le statut socio-économique et la consommation de tabac, d'alcool et de drogues sont mal comprises en République islamique d'Iran.

Objectifs : La présente étude avait pour objectif de mesurer les inégalités en matière d'éducation et de niveau de vie liées au tabagisme par cigarette, à l'usage de la houka, à la consommation de drogues illicites et d'alcool dans la province de Kermanshah, en République islamique d'Iran.

Méthodes : Nous avons utilisé les données de référence de l'étude menée à Ravansar sur les maladies non transmissibles. L'étude a permis de recueillir des informations sur les caractéristiques socio-économiques et démographiques, le tabagisme par cigarette et l'utilisation de la houka, la consommation d'alcool et de drogues illicites chez 10015 adultes âgés de 35 ans et plus entre 2014 et 2016. L'indice de concentration relative et l'indice de concentration absolue ont été utilisés pour mesurer les inégalités en matière d'éducation et de niveau de vie liées au tabagisme par cigarette, à l'utilisation de la houka et à la consommation de drogues illicites et d'alcool.

Résultats : Le tabagisme par cigarette concernait principalement les hommes et les femmes moins instruits et moins aisés. De même, la consommation de drogues illicites concernait essentiellement les hommes présentant un statut socio-économique plus faible. Par contre, l'utilisation de la houka et la consommation d'alcool étaient plus fréquentes chez les hommes dont le statut socio-économique était plus élevé.

Conclusions : Il existe des inégalités liées à l'éducation et au niveau de vie en matière de consommation de tabac, d'alcool et de drogues illicites dans l'ouest de la République islamique d'Iran. Les études futures devraient viser à identifier les principaux déterminants socio-économiques de ces inégalités dans la province de Kermanshah et en général en République islamique d'Iran.

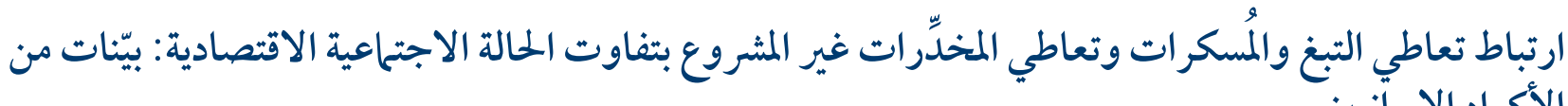

$$
\begin{aligned}
& \text { الأكر اد الإير آنينين } \\
& \text { فريد نجفي، محمد حجيز اده، يميى باسدار، يميى سليمي، بهروز مزة، بهز اد كرامي ماتين، بختيار بيروزي، ستار رضايي } \\
& \text { الخالاصة } \\
& \text { الخلفية: ثَّمَّة عدم فهم جيد للرو ابط بين الحالة الاجتهاعية الاقتصادية وتعاطي التبغ والمُسكرات والمخدِّرات في جمهورية إيران الإسلامية. } \\
& \text { الأهداف: قياس أوجه التفاوت في التعليم والثروة فيما يتعلق بتدخين السجائر، وتدخين النرجيلة، وتعاطي المخدِّرات غير المشروع، وتعاطي }
\end{aligned}
$$

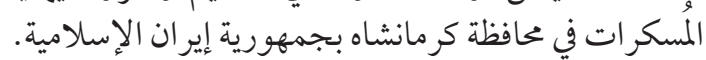

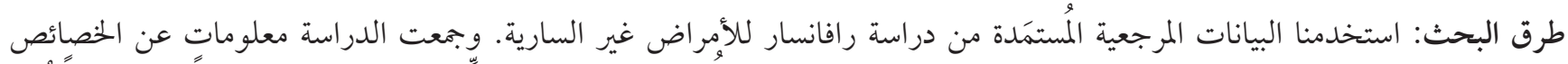

\section{References}

1. Harwood HJ, Fountain D, Livermore G. Economic cost of alcohol and drug abuse in the United States, 1992: a report. Addiction. 1999 May;94(5):631-5. http://dx.doi.org/10.1080/09652149933450 PMID:10563025

2. Miller T, Hendrie D. Substance abuse prevention dollars and cents: a cost-benefit analysis. DHHS Pub. No. (SMA) $07-4298$. Rockville, MD: Center for Substance Abuse Prevention, Substance Abuse and Mental Health Services Administration; 2008 (https://www.samhsa.gov/sites/default/files/cost-benefits-prevention.pdf, accessed 4 November 2019). 
3. Rice DP. Economic costs of substance abuse, 1995. Proc Assoc Am Physicians. 1999 Mar-Apr;111(2):119-25. http://dx.doi. org/10.1046/j.1525-1381.1999.09254.x PMID:10220806

4. Farimah Rezaei M, Pazhuheian F. Burden of drug and alcohol use disorders in Iran: findings from the Global Burden of Disease Study 2010. Arch Iran Med. 2015 Aug;18(8):480-5. http://dx.doi.org/015188/AIM.004 PMID:26265515

5. Rezaei S, Akbari Sari A, Arab M, Majdzadeh R, Poorasl AM. Economic burden of smoking: a systematic review of direct and indirect costs. Med J Islam Repub Iran. 2016 Jul 13;30:397. PMID:27579287

6. Max W. The financial impact of smoking on health-related costs: a review of the literature. Am J Health Promot. 2001 MayJun;15(5):321-31. http://dx.doi.org/10.4278/0890-1171-15.5.321 PMID:11502013

7. Rezaei S, Akbari Sari A, Arab M, Majdzadeh R, Mohammadpoorasl A. Estimating economic burden of cancer deaths attributable to smoking in Iran. J Res Health Sci. 2015 Fall;15(4):228-33. PMID:26728908

8. Akbari Sari A, Rezaei S, Arab M, Majdzadeh R, Matin BK, Zandian H. Effects of smoking on cost of hospitalization and length of stay among patients with lung cancer in Iran: a hospital-based study. Asian Pac J Cancer Prev. 2016;17(9):4421-6. PMID:27797255

9. Rezaei S, Karami Matin B, Hajizadeh M, Bazyar M, Akbari Sari A. Economic Burden of Smoking in Iran: A Prevalence-Based Annual Cost Approach. Asian Pac J Cancer Prev. 2017 Oct 26;18(10):2867-73. http://dx.doi.org/10.22034/APJCP.2017.18.10.2867 PMID:29072438

10. Nocon M, Keil T, Willich SN. Education, income, occupational status and health risk behaviour. J Public Health. 2007 Oct;15(5):401-5.

11. Currie J. Healthy, wealthy, and wise: socioeconomic status, poor health in childhood, and human capital development. J Econ Lit. 2009;47(1):87-122.

12. Elgar FJ, Roberts C, Parry-Langdon N, Boyce W. Income inequality and alcohol use: a multilevel analysis of drinking and drunkenness in adolescents in 34 countries. Eur J Public Health. 2005 Jun;15(3):245-50. http://dx.doi.org/10.1093/eurpub/ckio93 PMID:15985459

13. Richter M, Leppin A. Trends in socio-economic differences in tobacco smoking among German schoolchildren, 1994-2002. Eur J Public Health. 2007 Dec;17(6):565-71. http://dx.doi.org/10.1093/eurpub/ckmo10 PMID:17353201

14. Wagstaff A, Paci P, Van Doorslaer E. On the measurement of inequalities in health. Soc Sci Med. 1991;33(5):545-57. http://dx.doi. org/10.1016/0277-9536(91)90212-u PMID:1962226

15. Kakwani N, Wagstaff A, Van Doorslaer E. Socioeconomic inequalities in health: measurement, computation, and statistical inference. J Econom. 1997 Mar;77(1):87-103. https://doi.org/10.1016/So304-4076(96)01807-6

16. Wagstaff $A$. The bounds of the concentration index when the variable of interest is binary, with an application to immunization inequality. Health Econ. 2005 Apr;14(4):429-32. http://dx.doi.org/10.1002/hec.953 PMID:15495147

17. Erreygers G. Correcting the concentration index. J Health Econ. 2009;28(2):504-15.

18. Harper S, Lynch J. Trends in socioeconomic inequalities in adult health behaviors among US states, 1990-2004. Public Health Rep. 2007 Mar;122(2):177-89. http://dx.doi.org/10.1016/j.jhealeco.2008.02.003 PMID:18367273

19. Pierce JP, Fiore MC, Novotny TE, Hatziandreu EJ, Davis RM. Trends in cigarette smoking in the United States: educational differences are increasing. JAMA. 1989 Jan 6;261(1):56-60. PMID:2908995

20. Nagelhout GE, de Korte-de Boer D, Kunst AE, van der Meer RM, de Vries H, van Gelder BM, et al. Trends in socioeconomic inequalities in smoking prevalence, consumption, initiation, and cessation between 2001 and 2008 in the Netherlands. Findings from a national population survey. BMC Public Health. 2012 May 18;12(1):303. https://dx.doi.org/10.1186/1471-2458-12-303 PMID:22537139

21. Charafeddine R, Demarest S, Van der Heyden J, Tafforeau J, Van Oyen H. Using multiple measures of inequalities to study the time trends in social inequalities in smoking. Eur J Public Health. 2012 Aug;23(4):546-51. http://dx.doi.org/10.1093/eurpub/ckso83 PMID:22711785

22. Corsi DJ, Lear SA, Chow CK, Subramanian S, Boyle MH, Teo KK. Socioeconomic and geographic patterning of smoking behaviour in Canada: a cross-sectional multilevel analysis. PLoS ONE. 2013;8(2):e57646. https://dx.doi.org/10.1371/journal.pone.0057646 PMID:23469038

23. Barreto SM, de Figueiredo RC, Giatti L. Socioeconomic inequalities in youth smoking in Brazil. BMJ Open. 2013 Dec 2;3(12):e003538. http://dx.doi.org/10.1136/bmjopen-2013-003538 PMID:24302501

24. Patrick ME, Wightman P, Schoeni RF, Schulenberg JE. Socioeconomic status and substance use among young adults: a comparison across constructs and drugs. J Stud Alcohol Drugs. 2012 Sep;73(5):772-82. http://dx.doi.org/10.15288/jsad.2012.73.772 PMID:22846241

25. Charitonidi E, Studer J, Gaume J, Gmel G, Daeppen J-B, Bertholet N. Socioeconomic status and substance use among Swiss young men: a population-based cross-sectional study. BMC Public Health. 2016;16(1):333. http://dx.doi.org/10.1186/s12889-0162949-5. https://doi.org/10.1186/s12889-016-2949-5

26. Combes J-B, Gerdtham U-G, Jarl J. Equalisation of alcohol participation among socioeconomic groups over time: an analysis based on the total differential approach and longitudinal data from Sweden. Int J Equity Health. 2011 Feb 10;10(1):10. http://dx.doi. org/10.1186/1475-9276-10-10. PMID:21306654 
27. Ritterman ML, Fernald LC, Ozer EJ, Adler NE, Gutierrez JP, Syme SL. Objective and subjective social class gradients for substance use among Mexican adolescents. Soc Sci Med. 2009 May;68(10):1843-51. http://dx.doi.org/10.1016/j.socscimed.2009.02.048 PMID:19342140

28. Almeida-Filho N, Lessa I, Magalhães L, Araújo MJ, Aquino E, James SA, et al. Social inequality and alcohol consumption-abuse in Bahia, Brazil. Soc Psychiatry Psychiatr Epidemiol. 2005 Mar;40(3):214-22. http://dx.doi.org/10.1007/s00127-005-0883-4 PMID:15742227

29. Lintonen T, Rimpelä M, Vikat A, Rimpelä A. The effect of societal changes on drunkenness trends in early adolescence. Health Educ Res. 2000 Jun;15(3):261-9. http://dx.doi.org/10.1093/her/15.3.261 PMID:10977374

30. Kouvonen A, Lintonen T. Adolescent part-time work and heavy drinking in Finland. Addiction. 2002;97(3):311-8. https://doi. org/10.1046/j.1360-0443.2002.00091.x

31. Poorasl AM, Vahidi R, Fakhari A, Rostami F, Dastghiri S. Substance abuse in Iranian high school students. Addict Behav. 2007 Mar;32(3):622-7. http://dx.doi.org/10.1016/j.addbeh.2006.05.008 PMID:16815638

32. Redonnet B, Chollet A, Fombonne E, Bowes L, Melchior M. Tobacco, alcohol, cannabis and other illegal drug use among young adults: the socioeconomic context. Drug Alcohol Depend. 2012 Mar 1;121(3):231-9. http://dx.doi.org/10.1016/j.drugalcdep.2011.09.002 PMID:21955362

33. Amin-Esmaeili M, Rahimi-Movaghar A, Sharifi V, Hajebi A, Radgoodarzi R, Mojtabai R, et al. Epidemiology of illicit drug use disorders in Iran: prevalence, correlates, comorbidity and service utilization results from the Iranian Mental Health Survey. Addiction. 2016 Oct;111(10):1836-47. http://dx.doi.org/10.1111/add.13453 PMID:27177849

34. Jalilian F, Karami Matin B, Ahmadpanah M, Ataee M, Ahmadi Jouybari T, Eslami AA, et al. Socio-demographic characteristics associated with cigarettes smoking, drug abuse and alcohol drinking among male medical university students in Iran. J Res Health Sci. 2015 Winter;15(1):42-6. PMID:25821025

35. Momenabadi V, Hashemi SY, Borhaninejad VR. Factors affecting hookah smoking trend in the society: a review article. Addict Health. 2016 Apr;8(2):123-35. PMID:27882210

36. Abdollahifard G, Vakili V, Danaei M, Askarian M, Romito L, Palenik CJ. Are the predictors of hookah smoking differ from those of cigarette smoking? Report of a population-based study in Shiraz, Iran, 2010. Int J Prev Med. 2013 Apr;4(4):459-66. PMID:23671779

37. Hessami Z, Masjedi M, Sharifi H, Emami H, Kazempour M, Jamaati H. Characteristics of Iranian hookah smokers aged 15 and above: a primary report. Health Scope. 2016;5(4):e36011. http://dx.doi.org/10.17795/jhealthscope-36011. 